\title{
Legacies From a Holocaust of the Mind
}

\author{
Joanna Diane Caytas
}

Correspondence: Joanna Diane Caytas, University of Oxford, St. Catherine's College, Manor Road, Oxford, Oxfordshire OX1 3UJ, United Kingdom. E-mail: joanna.caytas@stcatz.ox.ac.uk

\author{
Received: December 26, 2018 Accepted: January 22, 2019 Online Published: February 1, 2019 \\ doi:10.5539/res.v11n1p86 \\ URL: https://doi.org/10.5539/res.v11n1p86
}

\begin{abstract}
In the Molotov-Ribbentrop Pact, Hitler and Stalin devised to partition Poland for all future. Toward their goal of enslaving the nation, the Nazis systematically exterminated the Polish intelligentsia and prohibited tertiary education to create a nation of serfs. Still, the Soviets and their lieutenants continued a policy with similar if largely non-lethal effects for another 45 years under the banner of social engineering. The fate of the Lwów School of Mathematics is a prominent example of brute atrocities but also of great resilience, enduring creativity and irrepressible revival. Among the world's most advanced biotopes of mathematics in the interwar period, the Lwów School suffered debilitating losses from Hitler's genocide, wartime emigration, and the post-war brain drain of defections inspired by communism. The Scottish Café was perhaps the best-known liberal scholarly hotbed of cutting-edge mathematical ideas east of Göttingen, the caliber of its patrons reflective of the most noteworthy mine of mathematical talent outside of Oxford, Cambridge, Paris and Moscow in its day. It is a conclusion strikingly evidenced by the Scottish Book: three-quarters of a century later, a quarter of the mathematical challenges described therein is still awaiting resolution.
\end{abstract}

Keywords: Scottish café, Polish mathematics, Lwów school of mathematics and logic, functional analysis, genocide, intelligentsia

\author{
'When pygmies cast such long shadows, \\ it must be very late in the day.' \\ Gian-Carlo Rota
}

\section{Preamble}

Pol Pot was not the first to target scholars for extinction. During six short years 1939-1945, all of Poland became the scene of some of the most abominable atrocities in human history: its neighbors Germany and Russia, under cover of deception and denial (Wirtz \& Godson, 2002), set out to annihilate a millennium-old bastion of occidental culture through unprecedented industrial-scale occupation, deportation, subjugation and expropriation of a nation of almost forty million, assassinating one-fifth of its population (Piotrowski, 1998), installing on its territory the extermination camps of the Holocaust, spoken of only in hushed tones even by historians seventy years after the events, and perpetuating for more than forty years after World War II socio-political engineering through restriction on education that inflicted enduring damages on Poland.

This paper will portray the futility of multiple attempts to assassinate the scientific mind of a nation by eliminating its most avant-garde thinkers by one cameo example: the Lwów-Warsaw School of Mathematics and Logic, seen through the anecdotal lens of its most famous free-spirited expression, the circle at the Scottish Café and its prodigious relic, the Scottish Book.

To understand the root causes of these events, one needs to look at Poland's 300-year history of partitions since the age of Catherine the Great, the specific ethno-cultural circumstances of its intelligentsia, and the strategies pursued by both Nazi and Soviet dictatorships in pursuit of their conflicting ambitions for world domination. Unlike any other nation, Poland was partitioned by its neighbors in 1772, 1793, 1795, 1815, 1832 - and a sixth time in 1939 (Brecher \& Wilkenfeld, 1997). The synchronicity of Intelligenzaktion, AB-Aktion and the Katyń Massacre, each discussed below, is believed by many historians, including Norman Davies (1982), to be evidence of the Reich and Soviet government acting in concert under a verbal understanding supplemental to the Molotov-Ribbentrop Pact (Kuźniar-Plota, 2004).

As early as 1844, Polish philosopher Karol Fryderyk Libelt had described inteligencja as those well-educated members of society who lead the people as scholars, teachers, clerics, or engineers because of greater enlightenment (Libelt, 1844/1869). Following three centuries of partitions, the patriotic commitment of Polish intellectuals was high. It constituted a major obstacle to any attempts at a de novo disenfranchisement. 
Hitler certainly did not mince words about his intentions:

Once more the Führer must point out that the Poles can only have one master, and that is the German; two masters cannot and must not exist side by side; therefore, all representatives of the Polish intelligentsia should be eliminated. This sounds harsh, but such are the laws of life. ${ }^{1}$

Himmler was even more explicit:

For the non-German population of the East there can be no type of school above the four-grade rudimentary school. The job of these schools should be confined to the teaching of counting (no higher than up to 500), the writing of one's name, and the teaching that God's commandment means obedience to the Germans, honesty, industry and politeness. Reading I do not consider essential. ${ }^{2}$

\section{The Big Picture: A Strategy to Neutralize a Restive Nation Cursed by Geography}

For half a century, from 1939-1989, a ferocious battle was waged against the elites of the Polish nation by its neighbors in at least eight chronologically distinguishable operations (see Table 1).

Table 1: Numbers of victims among Polish elites by German and Soviet operation, 1939-1989.

\begin{tabular}{l|l|l}
\hline \multicolumn{1}{c|}{ Event } & \multicolumn{1}{c}{ Estimated victims } & \multicolumn{1}{c}{ Time span } \\
\hline Operation Tannenberg $^{3}$ & 22,000 & August 1939- October 1939 \\
\hline Intelligenzaktion $^{4}$ & 60,000 & September 1, 1939- April 1940 \\
\hline AB-Aktion & 30,000 & May 16, 1940- September 1940 \\
\hline Katyń Massacre & 22,000 & March 5, 1940-April 10, 1940 \\
\hline Massacre of Lwów Professors & 45 & June 30, 1941 - July 26, 1941 \\
\hline Concentration Camps & $3,000,000$ & September 1939- December 1944 \\
\hline NKVD Killings & & September 17, 1939- after 1954 \\
\hline Dekulakization & $1,000,000$ & October 1944 - December 1989 \\
\hline
\end{tabular}

2.1 Operation Tannenberg

Starting weeks before September 1, 1939, 2000 Poles resident in Germany who were active in minority organizations were covertly arrested and killed. The "Special Prosecution Book Poland" (Sonderfahndungsbuch Polen), compiled by Reinhard Heydrich's office, identified over 61,000 members of the Polish elite: political activists, operatives, intellectuals, actors, former officers, gendarmes and others to be detained or shot by Einsatzgruppen (Szczęśniak, 2001). Of those listed, some 20,000 were, in fact, liquidated.

\subsection{Intelligenzaktion}

In 1939, Jews accounted for 40-50\% of Poland's educated class (Numerus Clausus, 1971). Over 3 million Jews lived in Poland, or $20 \%$ of world Jewry (in 1887, this estimate had been 30\%) (Gitelman, 2001). In at least ten coordinated regional operations, the aristocracy, intellectuals, teachers, entrepreneurs, social workers, military veterans, gendarmes, members of national organizations, priests, judges, political activists, and anyone who had attended secondary school, over 61,000 people, were targeted for arrest and execution (Wardzyńska, 2009) by Einsatzgruppen and Selbstschutz, the paramilitary organization of the German minority within Poland who had prepared the Sonderfahndungsbuch Polen in cooperation with the Abwehr between 1937-1939 (Lukas, 1986). Under Sonderaktion Krakau, 183 professors of Kraków's Jagiellonian University (Uniwersytet Jagielloński) and the Mining Academy (Akademia Górniczo-Hutnicza) were sent to Sachsenhausen and Dachau concentration camps (Burek, 2000).

\subsection{AB-Aktion}

Continuing Intelligenzaktion after May 16, 1940, Außerordentliche Befriedungsaktion (Extraordinary Operation of Pacification), or AB-Aktion in euphemistic Nazi parlance, carried out mass executions including one at Palmiry forest where over 7,000 community leaders, university professors, secondary school teachers and Catholic priests were

1 Memorandum of Martin Bormann dated October 2, 1940, introduced as evidence at the Nuremberg Trial as USSR-172 (Gumkowski \& Leszczynski, 1961).

2 “Stellungnahme und Gedanken zum Generalplan Ost des Reichsführers SS," dated April 27, 1942 (Gellately, 1996).

3 Unternehmen Tannenberg (1979).

4 Wardzyńska (2009).

5 Piotrowski (1998).

${ }^{6}$ NKVD executions along with starvation and other deaths resulting from deportation (Davies, 1982). 
murdered under the pretext of involvement in crimes (Noakes \& Pridham, 1990). Its purpose was to keep Polish resistance dispersed and to prevent a coordinated uprising during the planned German invasion of France (Ibid.). Arrestees not shot immediately were later transferred to concentration camps including recently inaugurated Auschwitz (Kuźniar-Plota, 2004; Fischer, 1999-2000).

\subsection{Katyń Massacre}

With Stalin's approval, Lavrentij Pavlovich Beria organized the industrial execution of 22,000 Polish military personnel with POW status - nearly half the Polish officer corps - at Katyń forest near Smoleńsk and elsewhere, such as at the Kalinin and Kharkiv NKVD prisons. Non-military detainees were arrested in Soviet-occupied Poland for being 'intelligence agents, gendarmes, landowners, saboteurs, factory owners, lawyers, officials, and priests' (Kuźniar-Plota, 2004). Identical charges had also motivated Intelligenzaktion and AB-Aktion. More than seven thousand prisoners were shot by just one man, long-time NKVD chief executioner major general Vasily Mikhailovich Blokhin. Specifically selected for the position by Stalin in 1926, Blokhin served Soviet internal intelligence in its metamorphotic incarnations Cheka, GPU, NKVD and OKGB under their successive heads Yezhov, Yagoda and Beria. Easily the most prolific official executioner in recorded world history, Blokhin personally killed many tens of thousands of Stalin's prisoners. His trophy collection included Bukharin, Kamenev, Radek, Tukhachevsky, Yagoda, Yezhov and Zinoviev (Glenday, 2010; Montefiore, 2005; Rayfield, 2005).

Blokhin's Katyń victims included one admiral, two generals, 24 colonels, 79 lieutenant colonels, 258 majors, 654 captains, 17 naval captains, over 200 pilots, 300 physicians, 3,420 NCOs, 85 privates, seven chaplains, three landowners, one prince, 43 officials, 31 refugees, 20 university professors, several hundred lawyers, engineers, teachers, and over 100 writers and journalists.

These executions were authorized by Stalin's secret order to Beria dated April 4, 1940, approving Beria's March 3, 1940 memorandum and proposal no. 794/5 (РГАСПИ Ф. 17 оп. 166 дело 621 лист 130, 2005) (Voroshilov, Molotov, Mikoyan, Kalinin and Kaganovich concurred) and by previous NKVD Order No. 00485, "On Liquidation of Polish Sabotage and Espionage Groups and Units of POW" (Polska Organizacja Wojskowa, Polish Military Organization), approved by the Politburo on August 9, 1937 and signed by Nikolai Yezhov (who had since been executed by Blokhin on February 4, 1940). 111,071 Polish citizens were shot pursuant to these orders, only a small fraction of them at Katyń (Petrov \& Roginski, 1997). The very fact that Polish POWs were exchanged with Germany (where a similar fate awaited them) under the Secret Protocol to the Molotov-Ribbentrop Pact, depending on their residence in either the German or Russian occupied part of Poland, is further evidence of both partitioners' complicity in the systematic annihilation of Polish intelligentsia (Davies, 1982).

\subsection{Massacre of Lwów Professors}

Immediately following Operation Barbarossa, the German invasion of the Soviet Union on June 22, 1941, the largest invasion in military history by both manpower and casualties involving 3.9 million soldiers along a $2,900 \mathrm{~km}$ frontline, the University of Lwów was closed and Einsatzgruppen set out to change the city's ethnic make-up. Lwów's Jewish population primarily practiced trades and the professions: tailors, milliners, jewelers, and opticians. $80 \%$ of tailors and $70 \%$ of barbers were Jewish, $74.1 \%$ of merchants, 1,150 of 1,700 practicing doctors, $41 \%$ of theatre workers, $43 \%$ of dentists, $45 \%$ of nurses, 2,200 lawyers (by comparison: 450 lawyers were ethnic Ukrainians). $76 \%$ of Galicjan Jews spoke Polish, 17\% spoke German, and only 5\% spoke Ukrainian (Nakonechny, 2006). Einsatzgruppen shot 7,000 Jews in ostensible reprisal for last-minute mass killings of Poles and Ukrainians by the 'Jewish-dominated NKVD' before the Wehrmacht's arrival. An SD report dated July 31, 1941 stated:

The population rounded up some 1,000 Jews and drove them to the prison that had been occupied by the Wehrmacht ... The Lvov prisons were filled with the corpses of murdered Ukrainians, between 3,000 and 4,000. Reliable information also indicates that some 20,000 Ukrainians, of whom at least 80 percent belong to the intelligentsia, were deported to inner Russia. Similar conditions were observed in the neighboring towns, e.g., Dobromil, Sambor and vicinity... As reprisal for these atrocities 7,000 Jews were picked up and shot (De Zayas, 2000).

The Abwehr had long established contacts with Stepan Bandera's Organization of Ukrainian Nationalists (OUN). Many of its members served in the Nachtigall Battallion (Abbot, 2004) under the command of the Abwehr's special operations unit Lehrregiment Brandenburg z.b.V. 800. There is some evidence that the Nachtigall Batallion rounded up a substantial number of detainees for execution. A target list of 25 Lwów professors had been prepared in 1938-39 by OUN students in Kraków (Albert, 1989). ${ }^{7}$ Although it is unlikely that they knew the purpose of their list, it focused on

\footnotetext{
${ }^{7}$ Others believe that Ukrainian nationalists were fully involved (Motyka, 2011).
} 
academics that had shown political or Polish nationalistic initiative, who were suspected of collaboration with the Soviet regime, or had served in a leadership capacity. Jewish faith was not a discernible criterion for listing, although the Jewish casualty count until February 1945 was as high among Lwów academics as it was throughout the rest of Poland. 25 professors, their spouses, sons over age 18, relatives, even guests found at their residences were rounded up and shot, beaten to death, or killed with a hammer or bayonet. Some were buried alive (Krakowscy i wrocławscy akademicy na Wzgórzach Wuleckich we Lwowie, 2001). Aside from these academics, virtually all of Lwów's Jewish population of 120,000 was murdered during WWII, right at the Lwów Ghetto or at the Bełżec extermination camp. Only 200-800 Jews from Lwów are estimated to have survived (Piotrowski, 1998).

\subsection{Concentration Camps}

In Aktion Reinhard, named after its principal overseer Reinhard Heydrich, some two million Polish citizens, predominantly Jews, perished in the extermination camps of Auschwitz, Bełżec, Sobibór and Treblinka under the supervision of Odilo Globocnik (Friedländer, 2007):

But while in Western Europe it was only those who were active opponents of the Nazi regime, or suspected as such, that were sent to the camps, in Poland everyone was a candidate because he belonged to a nation on whom sentence had been passed. The basic job of the concentration camp was to drive the prisoners to a 'natural' death after first having exploited them as slave labor (Gumkowski \& Leszczynski, 1961).

Inside or outside concentration camps, most Poles received just 600 calories per day, which lead to epidemics including over a million additional cases of tuberculosis compared to an identical prewar period (Ibid.).

\subsection{NKVD Killings}

Poland's Soviet-controlled post-war communist regime waged a battle of extermination against the remnants of the Polish Home Army (Armia Krajowa) until as late as 1963 (Polish Underground Soldiers 1944-1963 - The Untold Story, 2018). Reliable estimates of post-1945 killings instigated by the NKVD - later KGB - within Poland remain difficult but their number is substantial. The KGB's battle against Polish intellectuals continued through the Solidarity crisis including the murder of Fr. Jerzy Popiełuszko on October 19, 1984 (KGB 'involved' in murder of Polish priest, 2008). Between 1954-1984, the NKVD/KGB acted in Poland nominally through Polish agents of the Security Service of the Ministry of Internal Affairs (Stużba Bezpieczeństwa Ministerstwa Spraw Wewnętrznych (SB)). An additional estimated million of ethnic Poles east of the redrawn Soviet border perished by execution, in forced labor camps, or as collateral damage of deportation and resettlement (Davies, 1982). These casualty figures do not include victims of the wartime Katyń Massacre administered by the NKVD at the behest of Beria. Right after the start of the German attack on June 22, 1941, the NKVD liquidated 9,817 political prisoners in Lwów ahead of advancing German troops, having already deported most of the ethnically Polish population to Siberia in the two preceding years (Snyder, 2010).

\subsection{Dekulakization}

While Dekulakization resulted in 2.6 million victims of the Holodomor genocide in Ukraine and other Soviet Republics, Poland experienced no famine and no casualties during collectivization of its agriculture in 1948-1954. Still, collectivization in Poland was an outright failure far exceeding other Eastern European nations (Bereza, 2011). Disenfranchisement of kulaks and other 'class enemies of the people' continued almost until 1989 through denial of access to education beyond primary and later beyond secondary school, to respected or lucrative trades, or to officer's ranks in the armed forces - opportunities that would convey leadership status or social position. Everyone descending from pre-1945 intelligentsia families experienced immense difficulty gaining admission to tertiary education under this form of affirmative action that awarded heavy points (punkty za pochodzenie) for being, or descending from, workers or collective farmers (pochodzenie robotniczo-chlopskie). The system was officially but not actually phased out in 1956, and it remained in place as an ideology and policy of social engineering that imploded without lasting trace in the aftermath of 1989. Following student protests in 1968, students again had to submit 'political certificates' and many lost their scholarships (Balicki \& Szyr, 1964). This way, the People's Republic of Poland continued for 45 years a policy of class-based discrimination against a sizable part of its own citizenry by limiting access to education strikingly similarly to what Himmler did on ethnic grounds and with undisputedly more brutal means during the five years of German rule. Now it was socially targeted, not ethnically generalized. But the result was painfully similar, and it lasted seven times longer: access to education remained restricted in Poland between 1939 and 1989, for a half-century, by anti-intelligentsia warfare.

\section{Lwów as an Intellectual, Scientific and Cultural Center}

Once upon a time, there was a Polish city nicknamed 'little Vienna.' It changed its name and allegiance four times in one century. Before 1918, it was known as Lemberg, capital of the Austro-Hungarian Kingdom of Galicja and 
Lodomeria. When Poland resurrected in 1918 from its fifth partition between Austria, Germany and Russia, Lemberg was renamed Lwów and continued what it had been for centuries: a vibrant and dynamic multi-cultural center of the arts and sciences, the eastern-most outpost of occidental civilization. When the city ended up east of the Curzon Line, ${ }^{8}$ the Russians called it Lwow. Since 1991, it is known as Lviv in Western Ukraine. Among the partitioning powers, Austria had been the least stifling by far, investing heavily in belle époque architecture, administrative and legal institutions, and community infrastructure for a widely multilingual population. Even today, the city is still rich in Renaissance, Baroque and Neoclassical styles, known for its examples of Vienna Secession, Art Nouveau and Art Deco. The last Austrian census of 1910 reported Lemberg's population of 206,113 as 51\% Roman Catholic, 28\% Jewish and $19 \%$ Ukrainian Greek Catholic. 86\% spoke Polish, 11\% Ukrainian and 3\% German. There were Hungarian, Czech, Romanian and Armenian minorities. Yiddish was widely spoken (Statistische Zentralkommission, 1917). A distinct Lwów dialect had developed as a sociolect with roots in many languages besides Polish. Population in 1939 was 340,000 . By 1945, almost no Jews had survived. Today, Lviv's population approaches 800,000 - less than $1 \%$ of them Poles (Ethnic Groups in Lviv, 2004). Most of Lwów's Jewry was well-assimilated and secularized. Jews played a major role in the political, intellectual and economic life of the city and region. Most spoke Polish besides Yiddish and tended to vote aligned with Polish interests (Ulam, A.B., 2002). After 1918, Lwów quickly gained recognition as one of Poland's most avant-garde intellectual centers, rivaling Warsaw. Under Soviet occupation, it even rivaled Leningrad as the second-most important center of mathematics (Anisim Berman, as cited in Kałuża, 2005). It was a leading hub of Jewish and Ukrainian culture. While Lwów was the nucleus of the Hasidic movement in Eastern Europe, it was also a base for the Haskalah (Enlightenment) that developed in Germany and eventually led to Conservative and Reform Judaism in the United States. Since 1844, Lwów had the first 'progressive' synagogue anywhere. There was also a notable Crimean Karaite community - Jews of Turkic ethnicity who were exempt from the Nuremberg racial laws and from German persecution during the Third Reich (Ulam, A.B., 2002). Although Lwów and other Galicjan commercial and intellectual centers were overwhelmingly Polish-dominated, the majority of peasants had been Ukrainian (a.k.a. Ruthenian) already long before 1918.

\section{The Lwów-Warsaw School of Mathematics and Logic}

History of mathematics cannot be written without recognizing its fertile biotopes. While mathematicians require few tools beyond pencil, eraser, and blank sheet, the human mind thrives on cross-fertilization by the thoughts of others from different backgrounds. Since Sumerian times, there was little mathematical life outside significant intellectual centers, much less in hermitages. Outstanding mathematicians are seldom loners. Most thrive on collaboration. Such daily collaboration among peers was the greatest forte of the Lwów-Warsaw School of Mathematics and Logic (Ulam, S. in Mauldin, 1981). Lemberg was not greatly harmed by World War I, though military losses were heavy: some 510,000 Austrian casualties (Lemberg, 2005). It was taken in 1914 by the Russian Army but recaptured by Austria-Hungary in June 1915. Ravages during the Polish-Ukrainian War 1918-1919 were another matter. Despite the decisive Polish victory followed by pogroms and ethnic purges in Lwów and elsewhere (A Record of Pogroms in Poland, 1919), Galicja remained a center of Ukrainian nationalism during the interbellum period. Lwów was the seat of a Roman, Greek and Armenian archbishop, with significant cathedrals and synagogues (Suny \& Kennedy, 2001). The city had maintained much of Vienna's fin de siècle spirit including its urbane, liberal, erudite café society. No wonder that birds of an intellectual feather flocked together after hours at the University of Lwów. Uniwersytet Lwowski or Uniwersytet Jana Kazimierza, founded 1661 by king John II Casimir, had evolved from a former Jesuit collegium, and was long the only other Polish university after Kraków's Jagiellonian University. Its mathematical culture looked back at a relatively brief tradition since about 1879 (Domoradzki, 2011). A group of about a dozen mathematicians from the university and the Lwów Polytechnic working primarily on functional analysis, real analysis and probability theory soon became known as the Lwów School of Mathematics, later part of the greater Lwów-Warsaw School of Mathematics and Logic (Lwowsko-Warszawska szkoła matematyczna). This was a unique interwar phenomenon: some 30 scholars explored the application of mathematical methods to logical and philosophical questions (Ulam, S., 1983; Kuzawa, 1968) and contributed to the evolution of logic itself. One was Alfred Tarski, after 1939 at UC Berkeley, who contributed to model theory, metamathematics, algebraic logic, abstract algebra, topology, measure theory, mathematical logic, set theory, and analytic philosophy.

\section{The Scottish Café: Demonstrating the Legacies of Intellectual Genocide in a Microcosm}

History unfolds in multiple spheres, from the meta-level to the macro dimension to the microcosm of cause and effect as it determines individual acts and lives. Cognition has no more useful way to absorb policy than by examining, with

\footnotetext{
${ }^{8}$ Named after British Foreign Secretary George Curzon, this line represented the demarcation of Polish eastern borders proposed by the Supreme Allied Command after WWI in connection with Poland's Declaration of Independence (Alexander, 2008).
} 
the benefit of close observation, the effects of abstract plans and concepts upon living, breathing human beings and their livelihood and realities. What is more, it shows the limits and futility of grand schemes given the effectiveness of aggregate private individual response to ideology and geopolitics. The following part of this paper demonstrates the close interaction of global affairs with the life of the mind as it triggers profoundly personal responses with sometimes surprising priorities.

Lwów mathematicians routinely congregated on weekdays after five o'clock over coffee, cognac and cigars. In the beginning, patronage was split between the Café Roma, located a couple hundred yards from the university building (Ulam, S. in Mauldin,1981) popular with army officers and local intelligentsia, where Banach, Mazur, Sierpiński, Ruziewicz and others could be found while Ludwik Zalewski's Confectionery (Kałuża, 1985) attracted a more genteel group including Steinhaus, Łomnicki and Kuratowski. But soon, Banach became irritated by Café Roma's handling of his credit situation. Given Banach's popularity and intellectual charisma, his alternative across the street, the Kawiarnia Szkocka or Scottish Café at Akademicki Square 9, later renamed Prospekt Taras Shevchenko 27, became the 'place to be' for local mathematicians. Banach was a regular there, possibly due to his limited residential circumstances. Later, the place was renamed in Ukrainian Шотландська кав'ярня (Shotlandska Kawiarnia), then Desertniy Bar. Today, the venue houses Universal Bank. The Lwów School was pretty much the work of one compelling, immensely talented, charismatic personality, Stefan Banach, and of his discoverer and academic mentor, Hugo Steinhaus.

\subsection{The Scottish Book}

'A mathematician is a person who can find analogies between theorems; a better mathematician is one who can see analogies between proofs and the best mathematician can notice analogies between theories; and one can imagine that the ultimate mathematician is one who can see analogies between analogies.'

\section{Stefan Banach (Kałuża, 1985).}

Mathematicians' habit of writing down solutions whenever an idea struck led the Scottish Café circle often to the simplest option: the marble tables of the establishment, much to owner Zieliński's displeasure. But he did exact his revenge: every cleaning of the table tops erased all records of previous discussions. Some contained very important proofs.

Banach had met his beloved wife Łucja through Steinhaus. Née Łucja Janina Braus, she married Banach on October 19, 1920 at the Kraków church of St. Szczepan-on-the-Sands. Hailing from a family of artisans, Łucja supported herself (Kałuża, 1985). Always the practical woman, she earned her place in the pantheon of mathematics by purchasing in 1935 for $2 \frac{1}{2}$ złoty a large ruled school notebook with marble-patterned cardboard cover that everyone in their circle, including foreign visitors, could request from the proprietor to memorialize a problem, comment, idea or solution (Mauldin, 1981). And thus the "Scottish Book" (Ksiega Szkocka) was born, always kept at the cloakroom, faithfully guarded by the Cafe's cashier. By the time the Scottish Book was closed in 1941 following German occupation under Operation Barbarossa, it had become one of the most revered relics in the history of mathematics, repository of 193 significant mathematical problems of which just over $3 / 4$ were solved to date (Kałuża, 1985).

Of 37 contributors to the Scottish Book, 13 were visiting foreign scholars. Others, like Birnbaum, Eilenberg, Kac, Ulam or Zygmund, had emigrated to the United States before World War II. Of 20 scholars still in Poland after September 1, 1939, nine were murdered by the Germans: Auerbach, Bartel, Eidelheit, Łomnicki, Ruziewicz, Saks, Schauder, Schreier and Stożek. Two were killed by the Russians: Kaczmarz and Marcinkiewicz. Bartel, a mathematician and former president of the Lwów Polytechnic, though not himself a contributor to the Scottish Book, was also executed by the Gestapo. Thus, 60\% of Lwów's resident academics perished between 1939-1945.

After Banach died in 1945, Łucja Banach preserved the Scottish Book until her own death in 1954. After Lwów's postwar Soviet occupation, Łucja, like many of its surviving academics and professionals, relocated to Wrocław, the formerly German city of Breslau in Lower Silesia, where she is now buried (Mani, 2010).

In numerous cases, the author of a problem advertised incentives for its solution (Mauldin, 1981): Stanisław Mazur offered the most prizes (7) including 'a live goose' for a central question in functional analysis, problem 153 dated November 6, 1936, about the existence of Schauder bases in separable Banach spaces that was answered 1972 or 37 years later in the negative by Swedish mathematician Per Enflo. Hugo Steinhaus offered only two prizes: once, 100 grams of caviar, and the other time dinner at the noble restaurant George's. Stefan Banach, never prosperous, offered a prize just once - a bottle of wine. Von Neumann offered 'a bottle of whiskey of measure $>0$.' Ulam, whose larger family was affluent before the war and controlled banks and industrial enterprises and whose father was a prominent lawyer, offered 4 prizes of wine and beer, one of which he won himself. Ulam was also by far the most prolific poster of problems in the Scottish Book: 62 out of 193 in the book are his, followed by Mazur (47), Banach (25), Orlicz (14), and 
Schreier (10).

\subsection{The Principal Authors of the 193 Scottish Problems and Their Fate}

For as long as the intellectual venue of the Scottish Café existed, throughout the reversals of fortune of war, mathematicians came to the Scottish Café to entrust the Scottish Book with their unresolved problems and challenges. Below are brief descriptions of the problems' authors, their significance and contributions to mathematics. Their all-too-brief histories serve to highlight the quantitative as well as qualitative deprivation of outstanding minds the Polish nation suffered just in the city of Lwów, during just five of the fifty years Polish intelligentsia was under siege during the twentieth century. Starting almost every day at 5 p.m., regulars at the Café would hold deep, intense discussions powered by coffee just as much as by alcohol, sometimes loud, often heated, but at nearly all times with a good deal of respect and humor.

\subsubsection{Herman Auerbach (October 26, 1901 - August 17, 1942) (Executed by SS in Bełżec)}

Auerbach, professor at the University of Lwów, coauthor of a paper with Banach on the Hölder condition (Kałuża, 2005) was a regular at the Café and a relative of Ulam's mother, Anna Auerbach. As a Jew, he was imprisoned in the Lwów ghetto and transferred to Bełżec extermination camp where he perished (News on wartime fates of Polish mathematicians, 1945). He is the namesake of the Auerbach basis, a linear independent subset of a normed vector space, and of Auerbach's lemma, stating that an Auerbach basis always exists in any $n$-dimensional normed vector space (Bartoszyński, Džamonja, Halbeisen, Murnatová \& Plichko, 2005).

\subsubsection{Stefan Banach (March 30, 1892 - August 31, 1945)}

Much of Banach's life story reads like a movie script reminiscent of Good Will Hunting. He was born out of wedlock to a military father without permission to marry and a mother too poor to afford raising him. Within days of his birth, his mother left Stefan to his paternal relatives and vanished from his life. His father supported him financially until graduation from a Kraków high school in 1910, at which time Banach adopted style and mannerisms of a Kraków street urchin. He would keep those for the rest of his life. At first, he drifted from Kraków's Jagiellonian University to the Lwów Polytechnic, pursuing an engineering degree on a part-time basis for financial reasons, convinced, self-taught as he was, that mathematics had precious little left to be discovered.

One day in 1916, while ambling in Kraków's botanical garden, Hugo Steinhaus, then a professor at the University of Lwów, overheard an animated dialog of two young men about 'Lebesgue integral' and 'Lebesgue measure.' It was intriguingly unusual to hear what was then cutting-edge mathematics being discussed in park bench conversations, and Steinhaus' curiosity led to what he would later call his 'greatest scientific discovery.' Banach was not only self-taught, but he had done better as an autodidact than virtually the entire student body in mathematics did under prominent teachers - both in Kraków and in Lwów. Later, Steinhaus not only introduced Banach to his future wife but also arranged an assistantship with Antoni Łomnicki at Lwów Polytechnic. Because Banach did not hold an academic degree in mathematics (or in any subject, for that matter), a waiver from the minister of education was required to admit him to a PhD program without exposing him to senseless drudgery. Hugo Steinhaus and Kazimierz Twardowski served as his advisers. His dissertation on linear operations, defended in 1920, was a significant contribution that, with due credit to others, established functional analysis at the cutting edge of mathematics in its day (Banach, 1932). Just two years later, Banach not only saw his habilitation thesis approved but was also appointed professor extraordinary, holding the second chair in mathematics at the University of Lwów. Despite considerable improvement in his financial circumstances resulting from such recognition, expenses always exceeded Banach's revenues and, along with Sierpiński and Stożek, he found himself writing high school textbooks to add income (Kałuża, 2005). Soon after his appointment, Banach was widely popular as a distinguished, well-known scientist who authored unusually visionary scholarly publications in Polish, in remarkably smooth self-taught French, and, with the assistance of co-authors, in German. He supervised Mazur's dissertation and had strong influence on Ulam. Together with Steinhaus, he founded Studia Mathematica in 1929, a mathematics journal that publishes papers on functional analysis, general theory of orthogonal series, probability theory and related areas in English, French, German or Russian (Kałuża, 2005). In 1939, he was elected president of the Polish Mathematical Society (Kałuża, 2005).

Soviet occupation from 1939 to 1941 did not inconvenience Banach personally. He related well to prominent Soviet mathematicians like Sergey Sobolev, Lazar Lusternik, Nikolai Bogolubov and Pavel Alexandrov, visited them in Moscow and received them in Lwów (Kałuża, 2005). Exempt from military service since his youth as he was left-handed and had poor vision in his left eye (Kałuża, 2005), Banach was elected to the Lwów City Council where he helped the persecuted Polish minority.

German occupation from 1941 to 1944 brought much harder times because he found himself briefly detained by the Gestapo, perhaps on suspicion of Soviet sympathies. The university was shuttered. But Banach, not being Jewish and 
not having been among his colleagues summarily massacred at the Wzgórza Wuleckie or in the Bursa Abrahamowiczów building, survived with other academics by working at the typhoid vaccine laboratory of Rudolf Weigl's Bacteriological Institute by feeding his own blood to lice for an hour each day, all the while discussing mathematics with his colleagues. As a purveyor of strategic vaccine to the Wehrmacht, Banach secured his everyday existence in Lwów through a quasi-safe, quasi-official status. At least he was better off than most (Kałuża, 2005).

Once the Red Army cleared Poland of German occupation, Banach's name was mentioned in early 1945 as a possible minister of education in a post-war government (Kałuża, 2005). When Lwów again ended up east of the Curzon line in Western Ukraine, he was offered a mathematics chair at Kraków's Jagiellonian University. Unfortunately, Banach's remarkable luck that had carried him to international scholarly fame and through the war, had run out: a life-long chain smoker, he was diagnosed with lung and bronchial cancer in January 1945 to which he succumbed on the last day of August. Banach was buried in the crypt of his friend and colleague Riedl under massive participation of the Lwów scientific and academic community and what was left in town of the Polish element after widespread Ukrainian nationalist expulsions. In 1990, his ashes were transferred to the Crypt of the Distinguished at Kraków's Na Skatce Church. Five of Banach's papers and a textbook appeared posthumously (Ciesielska \& Ciesielski, 2008; Kałuża, 2005).

His legacy of 53 all-too-short years marks Banach as one of the greatest mathematicians not just of Poland but of the twentieth century (Ciesielski, 2007). His scholarly legacy included (1) functional analysis which looks for the big picture in differential equations by thinking of a differential operator as a linear map on a large set of functions. It is a branch of mathematical analysis based on the study of vector spaces that have a limit-related structure, and of the linear operators that act on these spaces within their structures (Weisstein, 2019); (2) Banach space, a vector space equipped with a norm that is complete in respect of that norm; (3) Banach bundle, a vector bundle each of whose fibers is a Banach space, that is a complete normed vector space. It may be of infinite dimension (Kosinski, 1993); (4) Banach algebra - an associative algebra $A$ over real or complex numbers that is also a Banach space (Mosak, 1975); (5) Banach fixed point theorem - it guarantees the existence and uniqueness of fixed points in certain self-maps of metric spaces and shows a constructive approach to finding these fixed points (Banach, 1922); (6) Banach limits (any linear functional that generalizes lim to apply to non-convergent sequences as well) (Moslehian, 2019); (7) Banach manifolds make it possible to extend manifolds to infinite dimensions. They are manifolds modeled on Banach spaces, topological spaces in which each point has a neighborhood homeomorphic to an open set in a Banach space (Lang, 1972); (8) Banach measure, a real-valued function on the algebra of all sets, whereby a rigid, finitely additive area can be defined for every set, even when a set does not have a true geometric area (Pap, 2002); (9) Banach-Mazur theorem (most well-behaved normed spaces are subspaces of the space of continuous paths) (Kleiber \& Pervin, 1969); (10) Banach-Mazur game, a topological game played by two players, trying to pin down elements in a set. It was the first infinite positional game under conditions of perfect information ever studied (Oxtoby, 1957); (11) Banach-Steinhaus theorem; (12) Banach-Tarski paradox (there exists a decomposition of a solid ball in three-dimensional space into a finite number of non-overlapping subsets that can be put back together in a different way to yield two identical copies of the original ball) (Banah \& Tarski, 1924); (13) Banach-Schauer theorem (if a continuous linear operator between Banach spaces is surjective, then it is an open map) (Rudin, 1991); (14) Banach-Stone theorem, allowing recovery of a compact Hausdorff space from the algebra of scalars, being the bounded continuous functions on the space (Araujo, 2006); (15) Hahn-Banach theorem, a key tool in functional analysis that permits the extension to the whole space of bounded linear functionals defined on a subspace of some vector space (Pincus, 1974).

Banach's image is on Polish 15-złoty and 40-groszy stamps and also on 2-złoty, 10-złoty and 200-złoty memorial coins, issued in April 2012 (Poland to issue coins to honor families who saved Jews, undated). An asteroid is named after him (Jet Propulsion Laboratory, undated).

\subsubsection{Kazimierz Władysław Bartel (March 3, 1882 - July 26, 1941) (Executed by Gestapo)}

Bartel was professor of mathematics and former president of Lwów Polytechnic. He had been prime minister of Poland three times, 1926, 1928-29, and 1929-1930 under Marshal Józef Piłsudski. After the Russian occupation of Lwów he had been offered a position in the Supreme Soviet, which he declined without any consequences and continued to teach at Lwów. Germany occupied Lwów on June 30, 1941. On July 2, 1941, Bartel was arrested by the Gestapo and detained at Brygidki prison. In custody, he was offered to head up a Polish puppet government under German control, which he declined. On Himmler's personal order, he was shot in prison on July 26, 1941, buried and later exhumed and cremated (Albert, 1989).

\subsubsection{Zygmunt Wilhelm Birnbaum (October 18, 1903 - December 15, 2000)}

Steinhaus supervised Birnbaum's dissertation. The eponymous Orlicz-Birnbaum spaces are a type of function space that generalizes $L^{p}$ spaces, relevant to both real analysis and harmonic analysis. In 1937, Birnbaum emigrated to New York as foreign correspondent for a Polish magazine and obtained a professorship at the University of Washington on 
recommendation of Richard Courant, Albert Einstein and Edmund Landau. He contributed to functional analysis, nonparametric testing and estimation, probability inequalities, survival distributions, competing risks, and reliability theory (Woyczynski, 2001).

\subsubsection{Karol Borsuk (May 8, 1905 - January 24, 1982)}

Borsuk's dissertation supervisor in Warsaw (1930) had been Stefan Mazurkiewicz, the man who, together with his doctoral student Sierpiński, had broken the Red Army's encryption during the Russo-Polish War of 1919-1921. Borsuk introduced the theory of absolute retracts, absolute neighborhood retracts, and cohomotopy groups now known as Borsuk-Spanier cohomotopy groups. After the war he became a member of the Polish Academy of Sciences (Kałuża, 2005).

\subsubsection{Marek Kac (August 3, 1914 - October 26, 1984)}

Immediately after completing his dissertation under Hugo Steinhaus, Kac prepared for emigration. On second try, he won a foreign scholarship from the Parnas Foundation with help from Steinhaus who was on the foundation's board. In November 1938, Kac left Poland at 24 (Kac, 1985). From 1939, he taught at Cornell University and became a full professor in 1947. A call by Rockefeller University in 1961 was followed in 1981 by the University of Southern California (Kac, 1985).

Kac's parents, brother and virtually all other relatives were murdered 1942 by Einsatzgruppe $C$ in Krzemieniec (now Kremenets), Volhynia, now Western Ukraine. His father, president of the local Judenrat, had refused cooperation with the Germans. Regardless of cooperation, only 14 Jews of many thousands in Krzemieniec survived the war (Kremenets, 2006).

Kac's best-known contributions are in probability and mathematical physics (Kałuża, 2005). They include the Erdös-Kac theorem, the fundamental theorem of probabilistic number theory (Riesel, 1994). The Feynman-Kac formula is a method of solving certain partial differential equations by simulating random paths of a stochastic process (Kac, 1949).

\subsubsection{Stefan Kaczmarz (1895 - 1940) (Executed by NKVD, Possibly in Katyń)}

In 1932, Stefan Kaczmarz was a student of Norbert Wiener at Trinity College, Cambridge. He is the namesake of the Kaczmarz algorithm for solving least means squares (LMS) problems (Maligranda, 2007) and of the Kaczmarz method for solving linear equations $A x=b$ which was rediscovered in the context of reconstruction of images after projections (Kaczmarz, 1937). After the Soviet invasion of 1939, Kaczmarz and others were rounded up by the NKVD as enemies of the Soviet people, possibly because of his Cambridge background. Because he does not figure on any Katyń list, some historians believe that he was shot upon arrest and not deported (Maligranda, 2007).

\subsubsection{Bronisław Knaster (May 22, 1893 - November 3, 1980)}

After a $\mathrm{PhD}$ at the Sorbonne under Stefan Mazurkiewicz, Knaster followed in his mentor's footsteps to earn fame in point-set topology and also maintained a strong interest in set theory. His wife, Maria Morska, was an artist who performed at Warsaw's Picador Café and recited poetry (Duda, 1987). He accepted a professorship at the University of Lwów and, after the war, at the University of Wrocław along with Steinhaus, with whom he shared a house in Wrocław's Biskupin section. Meetings of mathematicians he organized came to be called 'knasteria.' His contributions include the Knaster-Tarski theorem in order theory and lattice theory (Knaster \& Tarski, 1928); the Knaster-Kuratowski fan is a connected topological space rendered totally disconnected by removal of a single point, i.e., it has no non-trivial connected subsets; the Knaster condition exists in two forms: a partially ordered set has a Knaster condition upwards if any uncountable subset $A$ of $P$ has an upwards-linked uncountable subset while the opposite is true vice versa for the Knaster condition downward (Fremlin, 1984). Knaster and Kuratowski asked in 1920 whether a non-degenerate homogenous continuum (or pseudo-arc) in the Euclidean plane $\mathbf{R}^{2}$ must be a Jordan curve (Kałuża, 2005).

\subsubsection{Antoni Marian Łomnicki (January 17, 1881 - July 4, 1941) (Executed by Einsatzgruppen)}

Educated at Göttingen, Łomnicki headed the mathematics department at Lwów Polytechnic. He gave Banach his first academic job (Kałuża, 2005). Areas of interest included probability calculus and combinatorial spaces (Girlich, 2004). Łomnicki was murdered on Wzgórza Wuleckie during the Massacre of Lwów Professors on July 4, 1941 (Kałuża, 2005). For all his considerable recognition, popularity and long-time position within Lwów's scientific community, including years as dean of the faculty of mathematics, regrettably little of his work and scholarly materials survived.

\subsubsection{Stanisław Mazur (January 1, 1905 - November 5, 1981)}

The second-most prolific poster in the Scottish Book (47 problems compared to Ulam's 62), Mazur offered the most prizes, even though they were often modest in value. However, the same cannot be said of the famous live goose he offered on November 6, 1936 for answering problem no. 153, whether every Banach space has a Schauder basis 
(Mauldin, 1981; Enflo, 1973). During the Great Depression, a goose was anything but a trivial value. When the question was finally answered by Per Enflo in 1972 with proof in the negative, the value of a goose still held true in chronically undersupplied communist Poland. But Mazur, an active member of the Polish Communist Party since the early 1930s, had survived German occupation in the underground, accepted a professorship 1948 at Warsaw, become a member of the Polish Academy of Science as well as a senior party official for science, and could afford his generosity by the time the prize came due after 36 years of numerous unsuccessful attempts (O’Connor \& Robinson, Stanisław Mazur, undated). Mazur personally awarded Enflo the goose at the Stefan Banach Center in Warsaw during a nationwide broadcast (Mauldin, 1981). He had earned his PhD 1932 at Lwów under Banach whose closest cooperator he remained until Banach's death (Stanisław Mazur, undated).

Mazur's contributions include geometrical methods in linear and nonlinear functional analysis, Banach algebras, summability theory (Mazur was first to systematically use functional analysis in summability theory in 1930, followed by Banach (1932) and Orlicz (1933, 1955)) (Korevaar, 2004) game theory - particularly in issues of determinacy as were also central to the Banach-Mazur game (Wolfe, 1955) and recursive functions. The aforementioned Banach-Mazur theorem, the Banach-Mazur game, the Gelfand-Mazur theorem (a unital Banach algebra in which every non-zero element is invertible is isometrically isomorphic to $\mathbf{C}$ ) (Rudin, 1991) and the Mazur-Ulam theorem (if $V$ and $W$ are normed spaces over $\mathbf{R}$ and the mapping $f: V \rightarrow W$ is a surjective isometry, then $f$ is affine) (Mazur \& Ulam, 1932) bear his name.

\subsubsection{Józef Marcinkiewicz (March 30, 1910 - 1940) (Executed by NKVD in Katyń/Kharkiv)}

Marcinkiewicz joined the Scottish Café society as Banach's post-doc, having earned his doctorate under Antoni Zygmund at Stefan Batory University in Vilnius. In Lwów, he worked closely with Banach, Schauder and Kaczmarz. $\mathrm{He}$ is namesake of the Marcinkiewicz multiplier theorem, the Marcinkiewicz interpolation theorem and the Marcinkiewicz-Zygmund inequality, important in Fourier analysis and functional analysis (Zygmund, 1960).

Later Marcinkiewicz became a professor in Vilnius and visited England during the second half of August 1939. Against his colleagues' urgent advice, he returned to Poland, deposited voluminous unpublished mathematical manuscripts with his mother and enlisted as a lieutenant. His unit was assigned to the defense of Lwów, participating in operations there from September 20-21. On September 21, the Wehrmacht retreated and the Red Army took its positions, arresting all Polish officers who had commanded the defense of Lwów, including Marcinkiewicz. On September 25, they were deported to Starobielsk near Kharkiv, Ukraine. Three other officers from Lwów jumped off the train before it reached the Polish-Soviet border station Podwysokie. Marcinkiewicz had the same opportunity but he declined, rejecting salvation by 'desertion.' He figures on the Starobielsk camp's as well as on the Kozielsk camp's prisoners list and was thus apparently executed at Katyń. His parents were deported to Siberia and perished in a camp of starvation. Only sometime after the war, Marcinkiewicz's mathematical manuscripts, entrusted to and hidden by his parents, were accidentally discovered in an illegible and unfortunately unrecoverable state of decay (Dąbrowski \& Hensz-Chądzyńska, undated).

\subsubsection{Władysław Roman Orlicz (May 24, 1903 - August 9, 1990)}

Educated in Lwów and Göttingen and primarily interested in functional analysis and topology, Orlicz became a professor at the University of Poznań in 1937 and at the University of Lwów (then renamed State University Ivan Franko) from January 1940 to June 1941. Under German occupation he taught forestry at a commerce school in Lwów from August 1944 to February 1945. Then he returned to Poznań. Orlicz was namesake to Birnbaum-Orlicz spaces in real and harmonic analysis and to the Orlicz-Pettis theorem about convergence in weakly sequentially completely normed Banach spaces (Meise \& Vogt, 1992).

\subsubsection{Stanisław Ruziewicz (August 29, 1889 - July 12, 1941) (Executed by Einsatzgruppen)}

Ruziewicz earned his PhD under Sierpiński in Warsaw. As professor and head of the Department of Mathematics at the Academy of Foreign Trade in Lwów (Akademia Handlu Zagranicznego we Lwowie), he was a regular at the Scottish Café and served as dissertation supervisor of Stefan Kaczmarz. On July 12, 1941 Ruziewicz was murdered during the Massacre of Lwów Professors, roughly one week after the others (Kałuża, 2005).

\subsubsection{Stanisław Saks (December 30, 1897 - November 23, 1942) (Executed by Gestapo in Warsaw)}

Saks earned his $\mathrm{PhD}$ in 1922 at the University of Warsaw summa cum laude under Stefan Mazurkiewicz. He had participated in all three Silesian uprisings 1919-1921 and was awarded two medals for bravery. Saks was an active socialist and journalist for the weekly Robotnik (Worker). Despite his dissertation's success, habilitation thesis, a Rockefeller Fellowship in the United States, and broad experience as a tutor at the universities of Warsaw, Lwów and Vilnius, he was made a professor only in Lwów and only due to Banach (Zygmund, 1982). His areas of research included function theory and functionals. Named for him is, inter alia, the Denjoy-Luzin-Saks theorem, a function of 
generalized bounded variation in the restricted sense has a derivative almost everywhere. Denjoy and Luzin had stated weaker theorems before and Saks strengthened it in 1937 (Saks, 1937). The Denjoy-Young-Saks theorem states some possibilities for Dini derivatives of a function that hold almost everywhere. In 1915, Denjoy proved the theorem for continuous functions, Young extended it 1917 to measurable functions, and Saks extended it 1924 to arbitrary functions. It has considerable value in real analysis (Zygmund, 1982).

After the German occupation, Saks, a man of great moral and physical courage (Zygmund, 1982, forword to the 2nd edition 1965), joined the Polish underground yet again. In November 1942 he was arrested by the Gestapo in Warsaw and executed in prison on November 23, 1942 (Zygmund, 1982).

\subsubsection{Juliusz Paweł Schauder (September 21, 1899 - October 1943) (Executed by Gestapo in Lwów)}

Schauder became senior assistant in mathematics at the University of Lwów in 1935. On advice of Henryk Schaerf which, curiously enough, he promptly confirmed with Stefan Banach - he married one of his students, Emilia (Mila) Löwenthal, an orphan from Drohobycz whose grandfather had been expelled from the Jewish community there for being an atheist. After the German invasion in 1941, a Polish student who managed to escape to Switzerland conveyed a letter by Schauder to Heinz Hopf at the Federal Institute of Technology in Zurich, mentioning that he had many important new results but no conditions to write them down and that he feared for his life. He asked Swiss mathematicians to request Werner Heisenberg to intervene with German authorities to spare Schauder's life. Indeed, a letter was written by Zurich physicist Paul Scherrer to Heisenberg, but both Schauder and his wife Mila were killed - he in Lwów trying to escape deportation following arrest, she in Warsaw - and only his small daughter Ewa survived the war, hidden by nuns in a convent (Schaerf, 1993). In his final days, Schauder appears to have lacked even paper to record his mathematical results (Czyż, 1994).

Schauder made his greatest contributions to functional analysis, with wide applications throughout modern analysis. Named for him are the Schauder fixed point theorem, an extension of the Brouwer fixed point theorem to topological vector spaces including ones of infinite dimension, relevant for differential equations and differential geometry; Schauder bases, a generalization of orthonormal bases from Hilbert spaces to Banach spaces; and the Leray-Schauder theorem, a method that enables development of solutions for partial differential equations from a priori estimates in non-linear existence theory.

\subsubsection{Wacław Sierpiński (March 14, 1882 - October 21, 1969)}

Following his PhD from Kraków in 1906 under Stanisław Zaremba, Sierpiński lectured in Lwów 1908-1914. Zygmunt Janiszewski was his assistant (Kuratowski, 1972). He was dissertation supervisor to Stefan Mazurkiewicz and Stanisław Ruziewicz (Wacław Sierpiński, undated). Caught as an Austrian citizen behind Russian lines, he was detained and spent three years in Moscow with Nikolai Luzin, working primarily on projective and analytic sets. He was first to give an example of an absolutely normal number.

Sierpiński's most important contributions were in set theory, point set topology, number theory, and classic iterated function systems, an aspect of pre-Madelbrot fractal geometry, such as the Sierpiński square, Sierpiński gasket, Sierpiński carpet and Sierpiński pentagon (Kuratowski, 1972). He is also noted for the Sierpiński constant (Sierpiński, 1974), the Sierpiński game (connecting game-theoretical notions and topological properties) (Telgársky, 1975) and the Sierpiński space (Escardó, 2004), a finite topological space with two points, only one of which is closed, being the smallest example of a topological space which is neither trivial nor discrete, it has important applications in algebraic geometry, computation theory and semantics. During the Russo-Polish war of 1919-1921, Sierpiński and Mazurkiewicz broke Russian encryption for the Biuro Szyfrów, ensuring the defeat of general Tuchachevsky's troops in the battle on the Vistula (O'Connor \& Robinson, Wacław Sierpiński, undated). Almost as prolific as Paul Erdös, he published 724 papers and 50 books and survived World War II while teaching for the Underground University of Warsaw and smuggling manuscripts out for publication in Italy. After the 1944 Warsaw uprising, the Germans burnt down his house, library and personal letters but failed to capture Sierpiński (O’Connor \& Robinson, Wacław Sierpiński, undated).

\subsubsection{Władysław Hugo Dionizy Steinhaus (January 14, 1887 - February 25, 1972)}

Steinhaus, scion of a patrician Jewish family of intellectuals including an uncle who was a member of the Austrian Reichstag, received his PhD 1911 under David Hilbert in Göttingen. Among his doctoral students were Banach, Birnbaum, Kac, Orlicz, and Schauder (Władysław Hugo Dionizy Steinhaus, undated). His excellent classical training entailed advanced fluency in English, French, German, Latin and Greek. Together with Banach and Mazur (and, to a lesser extent, others at the Lwów School) he became a co-founder of functional analysis.

After the German occupation of Lwów, Steinhaus hid in the village of Berdechów from 1941 to 1945 under the identity and documents of recently deceased forest ranger Grzegorz Krochmalny provided to him by Polish underground 
resistance. There, he engaged in prolific underground teaching and writing, of which only a very small part has been published yet (Kac, 1985).

While undercover, Steinhaus worked on the 'cake-cutting problem' to decide how to divide a given resource in a manner which is 'fair' according to defined criteria (Knaster, 1946 citing a 1944 letter from Steinhaus; Steinhaus, 1949).

Having survived the war, he moved to the University of Wrocław where he became dean of the faculty of mathematics, physics and chemistry. Steinhaus, one of the founding fathers of the Scottish Book, revived tradition by starting the New Scottish Book. Its contents are regularly published in Colloquium Mathematicum, founded by Edward Szpilrajn (renamed Marczewski after 1940), himself a poster in the Scottish Book, professor at Wrocław and instrumental in the creation of a Polish scientific center there (Kałuża, 2005). Alas, continuity was well-intentioned but nothing is the same: no personality like Banach is in sight, there is no Scottish Café, and the New Scottish Book is kept in the library of the Institute of Mathematics. But Steinhaus put Wrocław on the map as a first-rate mathematical research center in Poland, just as he had done in Lwów.

With more than 170 publications to his name (List of the Scientific Works of Hugo Steinhaus, 1973), Steinhaus made significant contributions to a broad range of mathematical areas, among them mathematical logic, functional analysis, topology, trigonometric and Fourier series, probability theory (Urbanik, 1973), and much interdisciplinary work. He was also one of the founders of modern game theory and devised an early formal definition of strategy, preparing the ground for von Neumann's more complete analysis during and after the war. At the overlap of set theory and game theory, he stated the axiom of determinacy that is plainly inconsistent with the axiom of choice (in two-person games of length $\underline{\omega}$ under conditions of perfect information, a game in which both players choose integers is determined, meaning that one of the players pursues a winning strategy). It was considered by some to be 'proof' that there could be at most one God, since if there were two, they could be made to play the game, with the inevitable outcome that neither could be considered omniscient (Mycielski \& Steinhaus, 1962).

Steinhaus was first to propose $k$-clustering already in 1957, a method of cluster analysis based on partitioning $n$ observations into $k$ clusters so that each observation is grouped in the cluster with the nearest mean. It has important applications in data mining (Steinhaus, 1957).

Kac describes in detail how Steinhaus stood also at the cradle of probability theory, at the time still an emerging field far from recognized as actual mathematics. He laid the groundwork for axiomatization of probability by providing the first measure-theoretic axiom of coin-tossing. Another first was his definition of the independence of events and of the uniform distribution of a random variable (Kac, 1985).

Moreover, Steinhaus was first to conjecture what later became known as the ham sandwich theorem (let there be $n$ measurable objects of finite measure in $n$-dimensional space, it is possible to divide all of them in half with respect to their measure (volume) by a single (n-1)-dimensional hyperplane) (Steinhaus, 1938, Kac, 1985).

Steinhaus is also known for the Steinhaus-Johnson-Trotter algorithm (an algorithm that generates all the permutations of $n$ elements. Every permutation in the sequence generated by it differs from the previous permutation by substituting two adjacent elements of the same sequence) (Steinhaus, 1964), the Steinhaus polygon notation (a notation method to express extremely large numbers, sometimes well beyond astronomical numbers), ${ }^{9}$ the Steinhaus theorem (the difference set of any set of positive measure contains an open neighborhood of zero) (Stromberg, 1972) and the Banach-Steinhaus theorem (for a family of continuous linear operators - which are, therefore, bounded - and whose domain is a Banach space, pointwise boundedness is equivalent to uniform boundedness in operator norm) (Banach \& Steinhaus, 1927).

\subsubsection{Stanisław Marcin Ulam (April 13, 1909 - May 13, 1984)}

Like Banach, Ulam would soon emerge as one of the most creative and brilliant mathematicians of the twentieth century. Descended from a wealthy Jewish clan that was a household name in Eastern European banking, industry and various professions, his father Józef was a lawyer who, along with his sister Stefania, would perish at the hand of German forces. ${ }^{10}$ His uncle Szymon, chairman of a major bank, died at Dachau (Szymon Ulam, 2017). But Ulam, having earned his PhD 1933 at Lwów Polytechnic under Kazimierz Kuratowski and Włodzimierz Stożek (Stanisław Marcin Ulam, undated) had met John von Neumann (a fellow poster to the Scottish Book) in Warsaw. Von Neumann offered him a fellowship at the Institute of Advanced Studies in Princeton as of 1935. There, Ulam met George David Birkhoff, discoverer of the ergodic theorem, who invited him to apply to the newly created Society of Fellows at Harvard

\footnotetext{
${ }^{9}$ As they occur in cosmology, cryptology, mathematics, and statistical thermodynamics (Lloyd, 2002).

${ }^{10}$ Letter from cousin Juliusz Ulam to Stanisław Ulam dated March 16, 1945 (Anxiously from Lwów. Family Letters to Stanisław M. Ulam. Part II, undated).
} 
(Mauldin, 1981). After he received this Harvard fellowship, Ulam visited Lwów only during summer breaks (Ulam in Mauldin, 1981) - and yet, of all contributors, he still managed to post by far the most problems to the Scottish Book (62 out of 193). With his brother Adam, later a prominent Soviet and Cold War historian at Harvard, Ulam left Gdynia on the M/S Batory in August 1939, only to hear of Germany's attack on Poland by a nightly phone call from a relative on September 1, 1939 that reached him and Adam in Manhattan at a hotel on Columbus Circle. After the expiration of his Harvard fellowship, Ulam became an assistant professor at the University of Wisconsin. Von Neumann recruited him again in 1943, this time for the Manhattan Project, where he devised the Teller-Ulam design that became the basis for thermonuclear weapons (Mauldin, 1981). 1965 he accepted a professorship at the University of Colorado that remained his academic homestead for the rest of his life, interspersed with temporary functions at several other U.S. institutions.

Ulam is widely recognized for multiple groundbreaking contributions to the theory of measurable cardinals, measure in set theory, abstract measure, topology, ergodic theory, group theory and mathematical physics (Ciesielski \& Rassias, 2009; Erdös, 1985). He developed the Monte Carlo Method that searches for solutions to mathematical problems through a statistical sampling method with random numbers. It is now used in most mathematical software, weapons design, mathematical economics, and operations research (Stanisław Marcin Ulam, undated). He is namesake to the Mazur-Ulam theorem (Mazur \& Ulam (1932), the Ulam spiral (a simple way to visualize prime numbers that shows the tendency of certain quadratic polynomials to generate unusually large numbers of primes) (Stein, Ulam \& Wells, 1964), the Ulam conjecture (let $n$ be any natural number. If $n$ is even, divide it by 2 to arrive at $n / 2$. If $n$ is odd, multiply it by 3 and add 1 to arrive at $3 n+1$. Repeat the process indefinitely. The conjecture is that no matter what number the process starts with, it will always eventually reach 1), and the Fermi-Pasta-Ulam experiment (the apparent paradox in chaos theory that many complex physical systems exhibit almost exactly periodic rather than ergodic behavior. One of the possible solutions is based on the realization that many non-linear equations are exactly integrable) (Porter, Zabusky, Hu \& Campbell, 2009; Fermi, Pasta \& Ulam, 1955).

Following a severe bout with encephalitis in 1946, Ulam largely abandoned mathematical detail. He always had a visceral aversion to writing since his mind could never be contained by the limitations of his hands and eyes. In that regard, he resembled Banach closely. As Gian-Carlo Rota describes it, Ulam thereafter turned himself almost exclusively into a generator of visionary abstract ideas, highly successful and ground-breaking in most cases (Rota, 1987).

\section{Synopsis: Intelligentsia's Swipe as the Mantle of Karma}

Analysts have concluded from the Generalplan Ost that a Holocaust of 51 million Slavs had been intended in the occupied eastern territories. This view is corroborated by evidence of plans to greatly expand the Auschwitz complex to be capable of holding 400,000 prisoners simultaneously (Gumkowski \& Leszczynski, 1961). As for the Auschwitz-Birkenau crematories: 'Their deep foundations and concrete walls show that they were intended for long use, undoubtedly longer than that required by the campaign to exterminate the Jews' (Gumkowski \& Leszczynski, 1961). But for such a long-term perspective, any plan had to begin by first effectively decapitating the potential Polish leadership and intelligentsia (Szczęśniak (2001).

The genocidal tragedy of the Polish intelligentsia between 1939-1945 deferred the evolution of mathematics world-wide by about a decade in important fields including set theory, topology, transformation theory, ergodic theory, group theory, projective algebra, number theory, combinatorics, cryptology, graph theory, functional analysis, game theory, model theory, metamathematics, algebraic logic, abstract algebra, measure theory, mathematical logic and analytic philosophy. Despite the speed at which others responded to nature's horror vacui, all consequences of this holocaust of the mind for the intellectual life of the Polish nation have not healed in more than one generation.

The legacies those perished mathematicians committed to the Scottish Book, however, were not lost. Contributions by Polish-Jewish scientists to the Allied war effort were decisive for its success. It is difficult to imagine timely completion of the Manhattan Project without Stanisław Ulam. The number of Jewish refugee scientists was staggering. It included Edward Teller, Hans Bethe, Julius Robert Oppenheimer, Samuel Abraham Goudsmit, Isidor Isaac Rabi (another Galicjan), Leó Szilárd, Victor Frederick Weisskopf, Felix Bloch, Gregory Breit, Emilio G. Segrè, Klaus Fuchs, Otto Robert Frisch, and Rudolf Peierls (Hoddeson, Henriksen, Meade \& Westfall, 1993). The Polish-Jewish breach of Enigma encryption would have assured the destruction of the Third Reich even if the facts created by D-Day and the Red Army's advance to Berlin had not won the close race against progress made at Los Alamos. Enigma's machine encryption system and its operating procedures, cracked by the Polish Biuro Szyfrów, were delivered as a gift to the Western Allies five weeks before the outbreak of World War II, and, in Churchill's view, proved determinative of Allied victory (Winterbotham, 1974). President Roosevelt had explicitly provided for the use of nuclear weapons against the Third Reich. The commitment of predominantly Jewish émigré scientists to the Manhattan Project would not have been remotely as intense had it been driven solely by the exigencies of the Pacific war theater: their bomb had Hitler's name 
on it (Groves, 1962).

Moral, philosophical or ethical arguments aside: repression to preserve regimes and ideologies has always proved futile except for quite limited periods that were invariably followed by ignominy. They come at great human cost that still cannot deliver the desired result. History has unequivocally equated intelligentsia purges to other useless forms of human sacrifice, including those intended to bring rainfall, favorable trade winds, or abundant harvests. Save by coincidence, they never do, while ashes breed phoenices. Poland is living proof.

\section{Acknowledgments}

The author is most grateful to Anna Frajlich-Zając, Lori Fisler Damrosch and Oksana Kis for observations on the legal, sociological and philosophical aspects of genocide.

\section{References}

A Record of Pogroms in Poland (1919, June 1). The New York Times. Retrieved from https://www.nytimes.com/1919/06/01/archives/a-record-of-pogroms-in-poland-massacres-began-in-lemberg-accor ding.html

Abbot, P. (2004). Ukrainian Armies 1914-55. Oxford: Osprey Publishing.

Albert, Z. (1989). Kaźń Profesorów Lwowskich 1941. Wrocław: Wydawnictwo Uniwersytetu Wrocławskiego.

Alexander, M. (2008). Kleine Geschichte Polens ( $2^{\text {nd }}$ ed.). Stuttgart: Reclam.

Anxiously from Lwów. Family Letters to Stanislasw M. Ulam. Part II. In Adam B. Ulam. Retrieved from http://adamulam.org/anxious2.htm

Araujo, J. (2006). The noncompact Banach-Stone theorem. Journal of Operator Theory, 55(2), 285-294.

Aspray, W. (1988). Science, computers and People: From the tree of mathematics. In Ulam, S., Reynolds, M. C. \& Rota, G.-C. (Eds.). Isis, 79(4), 702-703.

Axler, S. (1997). The life of Stefan Banach. American Mathematical Monthly, 104, 577-579. https://doi.org/10.2307/2975096

Balicki, S. W., \& Szyr, E. (1964). Twenty Years of the Polish People's Republic. Warsaw: Państwowe Wydawnictwo Ekonomiczne.

Banach, S. (1922). Sur les opérations dans les ensembles abstraits et leur application aux équations intégrales. Fundamenta Mathematicae, 3, 133-181. https://doi.org/10.4064/fm-3-1-133-181

Banach, S. (1932). Théorie des opérations linéaires. Monografie Matematyczne (Vol.1). Warsaw: Subwencja Funduszu Kultury Narodowej.

Banach, S., \& Steinhaus, H. (1927). Sur le principe de la condensation des singularités. Fundamenta Mathematicae, 9, 50-61. https://doi.org/10.4064/fm-9-1-50-61

Banach, S., \& Tarski, A. (1924). Sur la décomposition des ensembles de points en parties respectivement congruentes. Fundamenta Mathematicae, 6, 244-277. https://doi.org/10.4064/fm-6-1-244-277

Barański, F. (1989). The limit problems for differential equations. Kraków: Politechnika Krakowska.

Bartoszyński T., Džamonja, M., Halbeisen, L., Murtinová, E., \& Plichko, A. (2005). On bases in Banach spaces. Studia Mathematica, 170(2), 147-171. https://doi.org/10.4064/sm170-2-3

Bereza, T. (2011, August 1). Metody 'gryfickie.' Tygodnik Powszechny. Retrieved from https://www.tygodnikpowszechny.pl/metody-gryfickie-139822

Braun, K. (1996). A History of Polish Theater, 1939-1989: Spheres of Captivity and Freedom. Westport, Connecticut: Greenwood Publishing Group.

Brecher, M., \& Wilkenfeld, J. (1997). A Study of Crisis. Ann Arbor, Michigan: University of Michigan Press. https://doi.org/10.3998/mpub.14982

Burek, E. (Ed.). (2000). Sonderaktion Krakau. Encyklopedia Krakowa. Kraków: Państwowe Wydawnictwo Naukowe.

Case, S. H. (2002). The Scottish Café. Sleepy Hollow, New York: Slapering Hol Press.

Ciesielska, D., \& Ciesielski, K. (2008), Stefan Banach remembered in Kraków. The Mathematical Intelligencer, 30(4), 31-35. https://doi.org/10.1007/BF03038094

Ciesielski, K. (2007). On Stefan Banach and some of his results. Banach Journal of Mathematical Analysis, 1(1), 1-10. https://doi.org/10.15352/bjma/1240321550 
Clodfelter, M. D. (2002). Warfare and Armed Conflicts- A Statistical Reference to Casualty and Other Figures, 1500-2000. ( $2^{\text {nd }}$ ed.). Jefferson, North Carolina: McFarland \& Company.

Czyż, J. (1994). Paradoxes of measures and dimensions originating in Felix Hausdorff's ideas. Singapore: World Scientific Publishing Co. https://doi.org/10.1142/1079

Dąbrowski, K., \& Hensz-Chądzyńska, E. (2002). Józef Marcinkiewicz (1910-1940). In commemoration of the 60th anniversary of his death. In Żelazko, W. (Ed.). Fourier analysis and related topics, Banach Center Publications (Vol. 56) (pp. 31-35). Warsaw: Polish Academy of Sciences, Institute of Mathematics. https://doi.org/10.4064/bc56-0-2

Davies, N. (1982). God's Playground. A History of Poland, Vol. 2: 1795 to the Present. Oxford: Oxford University Press.

Dawidowicz, A. L. (1981). Reminiscences of Leon Chwistek, Hugo Steinhaus and Włodzimierz Stożek. Wiadomości matematyczne, 23(2), 232-240.

De Zayas, A. -M. (2000). The Wehrmacht War Crimes Bureau, 1939-1945. Rockport, Maine: Picton Press.

Domoradzki, S. (2011). University. In The growth of mathematical culture in the Lvov area in the autonomy period (1870-1920) (pp. 80-162). Praha: Matfyzpress. Retrieved from https://dml.cz/bitstream/handle/10338.dmlcz/402156/DejinyMat_47-2011-1_6.pdf

Duda, R. (1987). Life and work of Bronisław Knaster (1893-1980). In Colloquium Mathematicum, 51, 85-102. https://doi.org/10.4064/cm-51-1-85-102

Duda, R. (2007). The discovery of Banach Spaces. History of Mathematics in Poland. Proceedings of the First Joint International Meeting of American Mathematical Society and Polish Mathematical Society.

Duda, R. (2009). Facts and Myths about Stefan Banach. Newsletter of the European Mathematical Society, 71, $29-34$.

Duda, R. (2011). The New Scottish Book. In Jakimowicz, E., Miranowicz E \& A (Eds.): Stefan Banach. Niezwykte życie i genialna matematyka (Stefan Banach - Remarkable Life, Brilliant Mathematics). Gdańsk: Gdańsk University Press.

Enflo, P. (1973). A counterexample to the approximation problem in Banach spaces. Acta Mathematica, 130(1), 309-317. https://doi.org/10.1007/BF02392270

Erdös, P. (1985). Ulam, the man and the mathematician. Journal of Graph Theory, 9, 445-449. https://doi.org/10.1002/jgt.3190090402

Escardó, M. (2004). Synthetic topology of data types and classical spaces. Notes in Theoretical Computer Science. (Vol. 87) San Francisco et al. Retrieved from http://cs.bham.ac.uk/ mhe/papers/entcs87.pdf

Ethnic Groups in Lviv (2004). In All-Ukrainian Census 2001. Retrieved from http://2001.ukrcensus.gov.ua/eng/results/general/nationality/Lviv/

Evans, L. C. (1998). Partial Differential Equations. Providence: American Mathematical Society.

Feigenbaum, M. (1982). Reflections of the Polish Masters: An Interview with Stan Ulam and Mark Kac. Los Alamos Science, 3(3), 54-65.

Fermi, E., Pasta, J., \& Ulam, S. (1955). Studies of Nonlinear Problems. Reprint Document LA-1940 (May 1955), 977-988. https://doi.org/10.2172/4376203

Fischer, B. B. (2000). The Katyn Controversy: Stalin's Killing Field. Studies in Intelligence.

Fleming, R. J., \& Jamison, J. E. (2003) Isometries on Banach Spaces: Function Spaces. Boca Raton, Florida: CRC Press.

Fremlin, D. H. (1984). Consequences of Martin's axiom. Cambridge tracts in mathematics. No. 84. Cambridge: Cambridge University Press. https://doi.org/10.1017/CBO9780511896972

Friedländer, S. (2007). The Years of Extermination: Nazi Germany and the Jews, 1939-1945. New York: Harper.

Gellately, R. (1996). Reviewed works: Vom Generalplan Ost zum Generalsiedlungsplan by Czeslaw Madajczyk; Der "Generalplan Ost." Hauptlinien der nationalsozialistischen Planungs- und Vernichtungspolitik by Mechtild Rössler; Sabine Schleiermacher. Central European History, 29(2), 270-274. https://doi.org/10.1017/S0008938900013170

Girlich, H. -J. (2005). Łomnicki - Steinhaus - Kolmogorov: Steps to a modern probability theory. In Wiesław, W. (Ed.), European Mathematics in the Last Centuries. Lectures presented at the Conference held at Będlewo, 26-30 April 2004 (pp. 47-56). Wrocław: Institute of Mathematics, Wrocław University. 
Gitelman, Z. (2001). The Holocaust. In A Century of Ambivalence: The Jews of Russia and the Soviet Union, 1881 to the Present (pp. 115-143). Bloomington: Indiana University Press.

Glenday, C. (2010). Guinness World Records 2010. New York, Random House.

Groves, L. (1962). Now it Can be Told: The Story of the Manhattan Project. New York: Harper \& Row.

Gumkowski, J., \& Leszczynski, K. (1961). Poland Under Nazi Occupation. Warsaw: Polonia Publishing House.

Guy, R. K. (1983). Don't try to solve these problems. American Mathematics Monthly, 90, 35-41.

Hoddeson, L., Henriksen, P. W., Meade, R. A., \& Westfall, C. L. (1993). Critical Assembly: A Technical History of Los Alamos During the Oppenheimer Years, 1943-1945. New York: Cambridge University Press (1993). https://doi.org/10.1017/CBO9780511665400

http://www.fas.org/sgp/othergov/doe/lanl/pubs/00285736.pdf

Ingarden, R. S. (1993). Juliusz Schauder - Personal Reminiscences. Topological Methods in Nonlinear Analysis. Journal of the Juliusz Schauder Center, 2. https://doi.org/10.12775/TMNA.1993.026

Jet Propulsion Laboratory, California Institute of Technology, Small-Body Database Browser. 16856 Banach (1997 YE8). Retrieved from https://ssd.jpl.nasa.gov/sbdb.cgi?sstr=Banach

Kac, M. (1949). On Distributions of Certain Wiener Functionals. Transactions of the American Mathematical Society, 65(1), 1-13. https://doi.org/10.1090/S0002-9947-1949-0027960-X

Kac, M. (1985). Enigmas of Chance: An Autobiography. Sloan Foundation Series. New York: Harper and Row.

Kac, M., \& Ulam, S. (1968). Mathematics and Logic: Retrospect and Prospects. New York: Praeger, Dover paperback reprint edition (1990).

Kaczmarz, S. (1937). Angenäherte Auflösung von Systemen linearer Gleichungen. Bulletin International de l'Académie Polonaise des Sciences et des Lettres. Classe des Sciences Mathématiques et Naturelles. Série A, Sciences Mathématiques, 35, 355-357.

Kałuża, R. (1996, 2005). Through a reporter's eyes: The life of Stefan Banach. Boston, Massachusetts, Basel and Berlin: Birkhäuser.

KGB 'involved' in murder of Polish priest. (2008, October 28). The Telegraph.

Kleiber, M., \& Pervin, W. J. (1969). A generalized Banach-Mazur theorem. Bulletin of the Australian Mathematical Society, 1, 169-173. https://doi.org/10.1017/S0004972700041411

Knaster, B. (1922). Un continu dont tout sous-continu est indécomposable. Fundamenta Mathematicae, 3, $247-286$. https://doi.org/10.4064/fm-3-1-247-286

Knaster, B. (1946). Sur le problème du partage pragmatique de H. Steinhaus. Annales de la Société Polonaise de Mathématique, 19, 228-230.

Knaster, B., \& Tarski, A. (1928). Un théorème sur les fonctions d'ensembles. Annales de la Société Polonaise des Mathématiques, 6, 133-134.

Kordos, M., \& Duda, R. (2011). The New Scottish Book. In Jakimowicz, E. \& Miranowicz, (Eds.). Stefan Banach. Niezwykte życie i genialna matematyka (Stefan Banach - Remarkable Life, Brilliant Mathematics). Gdańsk: Gdańsk University Press.

Korevaar, J. (2004). Tauberian theory: A century of developments. Series of Comprehensive Studies in Mathematics (Vol. 329). Berlin, Heidelberg, New York: Springer. https://doi.org/10.1007/978-3-662-10225-1

Kosinski, A. (1993). Differential manifolds. San Diego, New York, London: Academic Press, Inc.

Kosmowska, Irena. Karol Libelt jako działacz politiczny i społeczny. Poznań 1918.

Krakowscy i wrocławscy akademicy na Wzgórzach Wuleckich we Lwowie (2001). Alma Mater, 33.

Kremenets. (2006). Encyclopedia Judaica. New York: Macmillan.

Kuratowski, K. (1972). Wacław Sierpiński (1882-1969). Acta Arithmetica, 21, 1-5. https://doi.org/10.4064/aa-21-1-1-5

Kuratowski, K. (1980). A half century of Polish mathematics: Remembrances and reflections. Oxford: Pergamon Press and Warsaw: Państwowe Wydawnictwo Naukowe.

Kurtz, S. A., \& Simon, J. (2007). The undecidability of the generalized Collatz problem. Cai, J-Y., Cooper, S. B. \& Zhu, H. (2007). Proceedings of the 4th international conference on theory and applications of models of computation, 
TAMC 2007, held in Shanghai, China in May 2007. (pp. 542-553). https://doi.org/10.1007/978-3-540-72504-6_49

Kushner, T., \& Knox, K. (1999). Refugees in an age of genocide. Global, national and local perspectives in the twentieth century. London, New York: Frank Cass.

Kuzawa, M. G. (1968). Modern mathematics: The genesis of a school in Poland. New Haven, Connecticut: College and University Press.

Kuźniar-Plota, M. (2004). Decision to commence investigation into Katyń massacre. Departmental Commission for the Prosecution of Crimes against the Polish Nation. Press Release dated November 30, 2004. Retrieved from http://www.ipn.gov.pl/portal/en/2/77/Decision_to_commence_investigation_into_Katyn_Massacre.html

Lang, S. (1972). Differential manifolds. Reading, Massachusetts, London, Don Mills, Ontario: Addison-Wesley Publishing Co., Inc.

Lemberg. (2005). In: Death tolls for the man-made megadeaths of the $20^{\text {th }}$ century. Necrometrics. Retrieved from http://necrometrics.com/battles.htm\#Lemberg

Libelt, K. (1869). O miłości ojczyzny (On love of the fatherland). Poznan (1844), reprinted in: Libelt, K., Rozprawy, Cracow.

List of the scientific works of Hugo Steinhaus. Wiadomości matematyczne, 17(2), 12-28.

Lloyd, S. (2002). Computational capacity of the universe. Physical Review. Letters, 88(23), 237-901. https://doi.org/10.1103/PhysRevLett.88.237901

Lukas, R. C. (1986). Forgotten Holocaust. The Poles under German Occupation 1939-1944. Lexington, Kentucky: University Press of Kentucky.

Maligranda, L. (2007). Stefan Kaczmarz, 1895-1939. In Roczniki Polskiego Towarzystwa Matematycznego. Seria VI: Antiquitates Mathematicae, 15-61.

Maligranda, L., \& Wnuk, W. (2000). Władysław Orlicz, 1903-1990. In Roczniki Polskiego Towarzystwa Matematycznego. Seria II: Wiadomości Matematyczne, 86-147.

Mani, P. (2010). Mathematik an der Universität Bern im neunzehnten und zwanzigsten Jahrhundert. In Colbois, B., Riedtman, C., \& Schroeder, V. (Eds.). Math.ch/100. Schweizerische Mathematische Gesellschaft 1910-2010. (pp. 373-388). Zurich: European Mathematical Society Publishing House.

Mauldin, R. D. (1981). The Scottish Book: Mathematics from the Scottish Café (including selected papers presented at the Scottish Book conference held at North Texas State University, Denton, Tex., May 1979). Boston, Massachusetts, Boston, Basel and Berlin: Birkhäuser.

Mazur, S., \& Ulam, S. (1932). Sur les transformations isométriques d'espaces vectoriels normés. Comptes Rendues de l'Académie des Sciences, 194, 946-948.

Meier, A. (2008). Die Intelligenzaktion: Die Vernichtung der polnischen Oberschicht im Gau Danzig-Westpreußen. Saarbrücken: VDM Verlag Dr. Müller.

Meise, R., \& Vogt, D. (1992). Einführung in die Funktionalanalysis. Braunschweig: Vieweg. https://doi.org/10.1007/978-3-322-80310-8

Metropolis, N., \& Ulam, S. (1949). The Monte Carlo method. Journal of the American Statistical Association, 44, 335-341. https://doi.org/10.1080/01621459.1949.10483310

Montefiore, S. S. (2005). Stalin: The Court of the Red Tsar. New York: Vintage Books.

Mosak, R. D. (1975). Banach Algebras. Chicago Lectures in Mathematics. Chicago: University of Chicago Press.

Moslehian, M. S. (2019), Banach Limit. In MathWorld. Retrieved from http://mathworld.wolfram.com/BanachLimit.html

Motyka, G. (2011). Od rzezi wołyńskiej do akcji Wista: Konflikt polsko-ukraiński 1943-1947. Cracow: Wydawnictwo Literackie.

Mycielski, J., \& Steinhaus, H. (1962). A mathematical axiom contradicting the axiom of choice. Bulletin de l'Académie Polonaise des Sciences. Série des Sciences Mathématiques, Astronomiques et Physiques, 10, 1-3.

Nakonechny, Y. (2006). Shoa u Lvovi. Lviv: Piramida.

Necrometrics. (2005). Retrieved from http://necrometrics.com

Nekrich, A. M., Ulam, A. B., \& Freeze, G. L. (1997). Pariahs, Partners, Predators: German-Soviet Relations 
1922-1941. New York: Columbia University Press (1997).

News on wartime fates of Polish mathematicians. (1945). Bulletin of the American Mathematical Society, 51(11), 868-869.

NKVD Order No. $00485 . \quad$ In $\quad$ Wikipedia. $\quad$ Retrieved from http://en.wikipedia.org/wiki/NKVD_Order_\%E2\%84\%96_00485

Noakes, J., \& Pridham, G. (1990). Nazism: A History in Documents and Eyewitness Accounts 1919-1945. (Vols. 1 \& 2). New York: Schocken Books.

O’Connor, J. J., \& Robinson, E. F., Wacław Sierpiński. In MacTutor History of Mathematics Archive. Retrieved from http://www-history.mcs.st-andrews.ac.uk/Biographies/Sierpinski.html

O'Connor, J. J., \& Robertson, E. F. (2000). Stanisław Mazur. In MacTutor History of Mathematics Archive. Retrieved from http://www-history.mcs.st-andrews.ac.uk/Biographies/Mazur.html

Oxtoby, J. C. (1957). The Banach-Mazur game and Banach category theorem. In Contribution to the Theory of Games, Vol. III, Annals of Mathematical Studies, 39, 159-163.

Pap, E. (Ed.). (2002). Handbook of Measure Theory. Amsterdam: Elsevier Science / North Holland.

Petrov, N. V., \& Roginski, A. B. (1997). The Polish Operation of the NKVD. Repressions against Poles and Polish citizens (pp. 22-43). Moscow: Zvenya. In Russian: Петров Н.В., Рогинский А.Б. Польская операция НКВД 1937-1938 г2. // Репрессии против поляков и польских граждан / Под ред. А.Э. Гурьянова. - Москва: «Звенья» (22-43). Retrieved from http://www.memo.ru/history/POLAcy/00485ART.htm

Pincus, D. (1974). The strength of Hahn-Banach's Theorem. Victoria symposium on non-standard analysis. Lecture notes in Mathematics. (Vol. 369) (pp. 203-248). New York: Springer.

Piotrowski, T. (1998). Poland's holocaust: ethnic strife, collaboration with occupying forces and genocide in the Second Republic, 1918-1947. Jefferson, North Carolina: McFarland \& Company.

Poland to issue coins to honor families who saved Jews. In World of Coins. Retrieved from http://www.worldofcoins.eu/forum/index.php?action=printpage;topic $=14188.0$

Polish Underground Soldiers 1944-1963. The Untold Story (2018). In The Doomed Soldiers. Retrieved from http://www.doomedsoldiers.com/

Porter, M. A., Zabusky, N. J., Hu, B., \& Campbell, D. K. (2009). Fermi, Pasta, Ulam and the Birth of Experimental Mathematics. American Scientist, 97(6), 214-221.

Rayfield, D. (2005). Stalin and his hangmen: The tyrant and those who killed for him. New York: Random House.

Riesel, H. (1994). The Erdős-Kac Theorem. In Prime numbers and computer methods for factorization (2 ${ }^{\text {nd }}$ ed.) (pp. 158-159). Boston, Massachusetts: Birkhäuser.

Rota, G. C. (1987). The lost café. Los Alamos Science. Special Issue. Retrieved from https://permalink.lanl.gov/object/tr?what=info:lanl-repo/lareport/LA-UR-87-3600-03

Rota, G. -C. (1997, 2008). Indiscrete thoughts. Palombi, F. (Ed.). Boston, Massachusetts, Boston, Basel and Berlin: Birkhäuser.

Rudin, W. (1991). Functional analysis. International Series in Pure and Applied Mathematics. New York: McGraw-Hill ( $2^{\text {nd }}$ ed.).

Saks, S. (1937). Theory of the integral. Monografie Matematyczne. (Vol. 7) (2 $2^{\text {nd }}$ ed.). Warsaw and Lwów: G.E. Stechert $\&$ Co.

Saks, S., \& Zygmund, A. (1965). Analytic functions. Monografie Matematycne (Vol. 28) (2 ${ }^{\text {nd }}$ ed.). Warsaw: Państwowe Wydawnictwo Naukowe.

Schaerf, H. M. (1993). My Memories of Juliusz Schauder. Topological methods in nonlinear analysis. Journal of the Juliusz Schauder Center, 2.

Sierpiński, W. (1974). Oeuvres choisies. Warsaw: Polskie Wydawnictwo Naukowe - Editions Scientifiques de Pologne (Vol. 1).

Sierpiński. W. In Mathematics Genealogy Project. Retrieved from http://genealogy.math.ndsu.nodak.edu/id.php?id=12545

Snyder, T. (2010). Bloodlands: Europe between Hitler and Stalin. New York: Basic Books. 
Spiess, A., \& Lichtenstein, H. (1989). Unternehmen Tannenberg. Der Anlass zum Zweiten Weltkrieg. Korrigierte und erweiterte Ausgabe. Berlin, Frankfurt am Main: Ullstein.

Stanisław M. Ulam. (2018). In Encyclopedia Britannica. Retrieved from http://www.britannica.com/EBchecked/topic/613123/Stanislaw-Marcin-Ulam

Stanisław Marcin Ulam. In Mathematics Genealogy Project. Retrieved from http://www.genealogy.math.ndsu.nodak.edu/id.php?id=12682

Stanisław Mazur. In Mathematics Genealogy Project. Retrieved from http://www.genealogy.math.ndsu.nodak.edu/id.php?id=13056

Statistische Zentralkommission (1917). Österreichische Statistik. Vienna: K \& K Hof- \& Staatsdruckerei.

Stein, M. L, Ulam, S. M., \& Wells, M. B. (1964). A Visual Display of Some Properties of the Distribution of Primes. American Mathematical Monthly (Mathematical Association of America), 71(5), 516-520.

Steinhaus, H. (1938). A note on the ham sandwich theorem. Mathesis Polska, 9, 26-28.

Steinhaus, H. (1949). Sur la division pragmatique. Econometrica. (Supplement), 17, 315-319.

Steinhaus, H. (1950). Mathematical snapshots. Oxford, New York: Oxford University Press.

Steinhaus, H. (1957). Sur la division des corps matériels en parties. Bulletin of the Polish Academy of Sciences, 4(12), 801-804.

Steinhaus, H. (1964). One hundred problems in elementary mathematics. New York: Basic Books.

Stromberg, K. (1972). An elementary proof of Steinhaus's theorem. Proceedings of the American Mathematical Society, 36(1), 308.

Studia Mathematica. ISSN: 0039-3223 (Polish) and 1730-6337 (English). In Institute of Mathematics - Polish Academy of Sciences. Retrieved from http://journals.impan.gov.p1/sm/

Suny, R. G., \& Kennedy, M. D. (2001). Intellectuals and the articulation of the nation. Ann Arbor: University of Michigan Press.

Szczęśniak, A. L. (2001). Generalplan Ost. Plan zagłady Stowian. Radom: Polskie Wydawnictwo Encyklopedyczne.

Szymon Ulam. In Geni. Retrieved from https://www.geni.com/people/Szymon-Ulam/6000000011955119145

Telgársky, R. (1974). On topological properties defined by games. In Topics in Topology. Proceedings of the first Hungarian Colloquim at Keszthely 1972. Colloquia Mathematica Societatis János Bolyai. (Vol. 8, pp.193-223). Amsterdam: North-Holland.

Telgársky, R. (1975). Spaces defined by topological games. Fundationes Mathematicae, 88, 193-223.

Ulam, A. B. (2002). Understanding the Cold War. A Historian's Personal Reflections ( $2^{\text {nd }}$ expanded ed.). With a new introduction by Paul Hollander. Piscataway, New Jersey: Transaction Publishers.

Ulam, S. (1983). Adventures of a Mathematician. New York: Charles Scribner's Sons.

Unternehmen Tannenberg. (1979, August 20). Der Spiegel 34/1979. Retrieved from http://www.spiegel.de/spiegel/print/d-39908700.html

Urbanik, K. (1973). The ideas of Hugo Steinhaus on probability theory.” Wiadomości matematyczne. 17(2), 39-50.

Visser, J. M. (2003). Talking about the unknown. Tech Trends, 47(1), 5-22.

Wardzyńska, M. (2009). Byt rok 1939. Operacja niemieckiej policji bezpieczeństwa w Polsce. Intelligenzaktion. Warsaw: Instytut Pamięci Narodowej.

Weissstein, E. W. (2019). Functional Analysis. In MathWorld. Retrieved from http://mathworld.wolfram.com/FunctionalAnalysis.html

Winterbotham, F. W. (1974). The Ultra Secret. London, Weidenfeld and Nicolson.

Wirtz, J. J., \& Godson, R. (2002). Strategic denial and deception: The twenty-first century challenge. Piscataway, New Jersey: Transaction Publishers.

Władysław Hugo Dionizy Steinhaus. In Mathematics Genealogy Project. Retrieved from http://genealogy.math.ndsu.nodak.edu/id.php?id=7383

Wójcik, Z. (1962). Rozwój pojęcia inteligencji, Wrocław, Warsaw \& Cracow: Wydawnictwo Polskiej Akademii Nauk.

Wolfe, P. (1955). The strict determinateness of certain infinite games. Pacific Journal of Mathematics, 5, Suppl. I, 
841-847.

Woyczynski, W. (2001). Seeking Birnbaum, or nine lives of a mathematician. Mathematical Intelligencer, 23, 36-40.

Zygmund, A. (1960). Józef Marcinkiewicz. Wiadomości Matematyczne, 4, 11-41.

Zygmund, A. (1982). Stanisław Saks (1897-1942). Wiadomości Matematyczne, 24(2), 145-156.

РГАСПИ Ф. 17 оп. 166 дело 621 лист 130. Подлинник (2005). In Pravda о Katyn. Retrieved from http://katyn.ru/index.php?go=Pages\&in=view\&id=6

\section{Copyrights}

Copyright for this article is retained by the author(s), with first publication rights granted to the journal.

This is an open-access article distributed under the terms and conditions of the Creative Commons Attribution license (http://creativecommons.org/licenses/by/4.0/). 